技術用語解説

\section{食品添加物（Food additives）}

食品添加物については，すでに本誌 32 巻第 10 号にお いて解説しているので，基本的なことがらはそちらを参 照していただき，ここでは，その後の改正を中心に解説 する.

\section{1. 定}

食品衛生法第 2 条に規定されているように「食品の製 造の過程において又は食品の加工若しくは保存の目的で, 食品に添加，混和，浸潤その他の方法によって使用する ちの」であり，化学的合成品（化学的手段により元素又 は化合物に分解反応以外の化学反応を起こさせて得られ た物質）と天然物がある．化学的合成品については，厚 生大臣が指定したものしか使用出来ないが，天然物は腐 敗，変敗していたり，有毒若しくは有害な物質が含まれ ていなければ制限なく使用できる，しかし，本来，物質 の安全性を考える際は，化学的合成品も天然物も同等に 扱うべきであるとの考えが浸透し，後述するように，表 示の面では，両者を同等に扱うようになった。

\section{2. 指定の追加あるいは削除}

（1）追加指定品目（平成 3 年 1 月 17 日告示） 食用赤色 40 号 着色料 アスコルビン酸パルミチン酸エステル グルタミン酸カリウム 酸化防止剂 グルタミン酸カルシウム 調味料 グルタミン酸マグネシゥム 調味料 クエン酸カリウム 調味料 調味料 水酸化カリウム 食品製造用剂 食用赤色 40 号は，輸入菓子のために，カリゥム塩は 加工食品中のナトリゥムの低娍のために指定された。

（2）指定削除品目（平成 3 年 3 月 27 日告示）

$\begin{array}{ll}\text { グリチルリチン酸三ナトリゥム } & \text { 甘味料 } \\ \text { 次亜塩素酸 } & \text { 殺菌漂白郕 } \\ \text { チアミンナフタレン-2, 6-ジスルホン酸塩, チアミン } \\ \text { フタリン酸 } & \text { 強化用 } \\ \text { デヒドロ酢酸 } & \text { 保存料 }\end{array}$

これらはほとんど使用実績がないか（グリチルリチン 酸三ナトリウム), 日本独自のもので国際的安全性評価 がなされていないあの（デヒドロ䣫酸）などである。
3. 化学的合成品以外の食品添加物の表示について 平成 3 年 7 月 1 日から，化学的合成品であるかないか にかかわらず全ての食品添加物が表示されるようになっ た、ただし，いくつかの例外がある.

（1）表示の免除

以下のものは表示しなくてよい.

(1) 加工助剂

食品の加工の際に添加される物であって，当該食品 の完成前に除去されるもの，当該食品の原材料に起 因してその食品中に通常含まれる成分と同じ成分に 変えられ，かつ，その成分の量をあきらかに增加さ せるものでないすの，または当該食品中に含まれる 量が少なく，かつ，その成分に上る影掣を当該食品 に及ばさないすの.

(2) 栄強化の目的で使用されるもの

(3) キャリーオーパー

食品の原材料の製造又は加工する過程において使 用され，かつ当該食品の製造又は加工の過程におい て使用されないものであって，当該食品中では当該 物が効果を発揮することができる量より少ない量し か含まれないものをいう.

何がキャリーオーバーに相当するかは，難しい問題で 個別に判断することになっている.

（2）表示の方法

表示は物質名によるのが原則であるが，簡略名あるい は種別名によることもできる.

イーストフード，ガムベース，苦味料，酵素，光択剤， 香料，酸味料，調味料，豆腐用凝固剂，乳化剂， $\mathrm{pH}$ 調 整剂については一括名で表示できる。

甘味料, 着色料, 保存料, 增粘剤, 安定郕, ゲル化用 又は糊料，酸化防止剂，発色剂，漂白剂，防かび刘又は 防ばい郕については，その用途名を併記する必要がある。

なお，化学的合成品以外の食品添加物の物質名につい ては，告示されたものを使用する，また，告示りストに ない物質を使用するときは，遅滞なく保健所長あて届け 出る必要がある.

\section{点考文 献}

田島 真: 日食工誌，32，786（1985）。 (実践女子大学) 田島 飓 